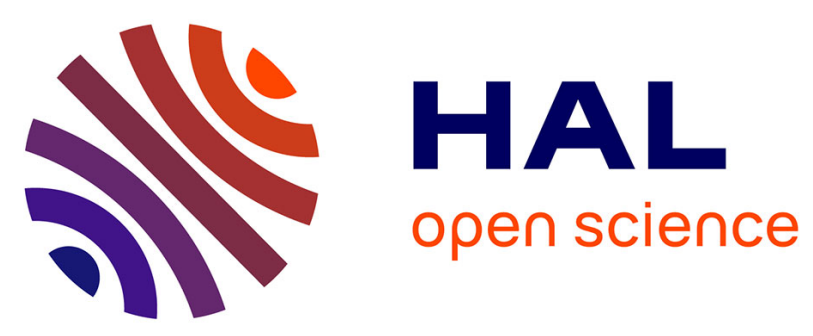

\title{
Glacier fluctuations during the Late Glacial and Holocene on the Ariège valley, northern slope of the Pyrenees and reconstructed climatic conditions
}

Vincent Jomelli, Emmanuel Chapron, Vincent Favier, V.R. Rinterknecht, Regis Braucher, Nicolas Tournier, Simon Gascoin, Renaud Marti, Didier Galop, Stéphane Binet, et al.

\section{To cite this version:}

Vincent Jomelli, Emmanuel Chapron, Vincent Favier, V.R. Rinterknecht, Regis Braucher, et al.. Glacier fluctuations during the Late Glacial and Holocene on the Ariège valley, northern slope of the Pyrenees and reconstructed climatic conditions. Mediterranean Geoscience Reviews, 2020, 2 (1), pp.37-51. 10.1007/s42990-020-00018-5 . insu-02476511

\section{HAL Id: insu-02476511 https://hal-insu.archives-ouvertes.fr/insu-02476511}

Submitted on 10 Nov 2020

HAL is a multi-disciplinary open access archive for the deposit and dissemination of scientific research documents, whether they are published or not. The documents may come from teaching and research institutions in France or abroad, or from public or private research centers.
L'archive ouverte pluridisciplinaire HAL, est destinée au dépôt et à la diffusion de documents scientifiques de niveau recherche, publiés ou non, émanant des établissements d'enseignement et de recherche français ou étrangers, des laboratoires publics ou privés. 


\title{
Glacier fluctuations during the Late Glacial and Holocene on the Ariège valley, northern slope of the Pyrenees and reconstructed climatic conditions
}

\author{
Vincent Jomelli ${ }^{1,4} \cdot$ Emmanuel Chapron $^{2} \cdot$ Vincent Favier $^{3} \cdot$ Vincent Rinterknecht $^{1,4} \cdot$ Régis Braucher $^{4}$. \\ Nicolas Tournier ${ }^{2}$. Simon Gascoin ${ }^{5} \cdot$ Renaud Marti $^{6}$. Didier Galop ${ }^{2}$. Stéphane Binet ${ }^{7}$. Cesar Deschamps-Berger ${ }^{5}$. \\ Helene Tissoux $^{8,9} \cdot$ Georges Aumaitre ${ }^{4}$. Didier L. Bourlès ${ }^{4} \cdot$ Karim Keddadouche ${ }^{4}$
}

Received: 14 November 2019 / Revised: 13 January 2020 / Accepted: 18 January 2020

(c) Springer Nature Switzerland AG 2020

\begin{abstract}
The glacier evolution from two valleys located near Vicdessos, French Pyrenees, is deciphered from 17 in situ cosmic ray exposure (CRE) dating. In the Picot valley, Late Glacial glacier advances were documented during Heinrich Stadial 1 (HS1), while a rock glacier developed or was reactivated during the mid-Holocene. In the upper Médécourbe valley, the largest visible ice extent occurred during the Younger Dryas (YD) or earlier. At least two moraines formed during the early Holocene were dated, while an undated moraine located close to the head of the catchment may have been formed either during the Late Holocene or the Little Ice Age. A mass balance model suggests that a temperature about $5.1^{\circ} \mathrm{C}$ cooler than today, without precipitation change, would be necessary to form a moraine at the base of the Picot catchment during HS1 at $2000 \mathrm{~m}$ a.s.l. A temperature about $3.9^{\circ} \mathrm{C}$ cooler than today is necessary to explain a moraine formed during the Late Glacial-YD transition at Médécourbe at $2200 \mathrm{~m}$. Comparing CRE dating from Picot and Médécourbe with those in the Pyrenees and the Alps highlights original glacial patterns. In the Picot catchment whose summit is below the current regional ELA, the absence of YD and Late Holocene moraines is consistent with the general low-altitude deglaciation trend documented in the northern and southern slope of the Pyrenees, but differs from high-altitude Pyrenean and Alpine records. However, due to specific geomorphological conditions, the glacial evolution of the Médécourbe valley took place differently compared to other low-altitude catchments in the Pyrenees.
\end{abstract}

\section{Article Highlights}

- CRE dating revealed moraines formed during the Heinrich Stadial 1(HS1) and the Late Glacial-Younger Dryas (YD) transition in Ariège valley (French Pyrenees).

- About $5.1^{\circ} \mathrm{C}$ and $3.9^{\circ} \mathrm{C}$ cooler than today without change in precipitation would explain the HS1 and Late Glacial-YD transition moraines formation.

- The evolution of the glacier fluctuation from the deglaciation may depend on the size of the accumulation area.

Vincent Jomelli

vincent.jomelli@lgp.cnrs.fr

1 LGP UMR 8591 CNRS Paris 1 Panthéon-Sorbonne University CNRS, 92195 Meudon, France

2 GEODE Laboratory UMR 5602 CNRS-Université Toulouse Jean Jaurès, 5 Allée A, Machado, 31058 Toulouse cedex 1, France

3 IGE UMR 5001 CNRS-IRD-Université Grenoble Alpes, Grenoble, France

4 CEREGE, UMR 34 Aix-Marseille University-CNRS-IRD-Coll, France-INRAE, 13545 Aix-en-Provence, France
5 Centre d'Etudes Spatiales de la Biosphère (CESBIO), Université de Toulouse, CNES/CNRS/INRA/IRD/UPS, 31401 Toulouse, France

6 Maison de la Télédétection, 500 Rue Jean François Breton, 34090 Montpellier, France

7 ISTO UMR 7327 CNRS-BRGM-Université d'Orléans, 1A rue de la Ferollerie, 45100 Orléans, France

8 BRGM, DGR/Géologie de l'aménagement des Territoires, 3 Av. Claude-Guillemin, 45060 Orléans, France

9 UMR 7194 Histoire Naturelle de l'Homme Préhistorique, CNRS-MNHN, 1 rue René-Panhard, 75013 Paris, France 
- Holocene moraines including Little Ice Age on the southern and northern slope of the Pyrenees, as is the case in the Alps, are evidenced in catchments with a current accumulation area, even if the magnitude of these advances may differ in the two regions.

- Catchments without a current accumulation area undergo in most cases a different evolution without Holocene moraines. However, local effects may modify this distinction based on catchment characteristics.

Keywords HS1 $\cdot$ YD $\cdot$ Holocene $\cdot{ }^{10}$ Be ages $\cdot$ Pyrenees $\cdot$ Glaciological model

\section{Introduction}

During the past 2 decades, increasing attention has been paid worldwide to document glacier fluctuations during the Late Glacial and Holocene, using in situ-produced cosmogenic nuclides (Solomina et al. 2015, 2016). Despite this extensive interest, knowledge relative to the glacier fluctuations in the Pyrenees during this period of time remains limited (Pallàs et al. 2006; Delmas et al. 2008, 2011; Palacios et al. 2017) (Fig. 1). The Pyrenees constitute a mountain range in southwest Europe that forms a natural border between Spain and France with an E-W orientation. The range extends for about $400 \mathrm{~km}$ from the Atlantic Ocean to the west to the Mediterranean Sea to the east. The location

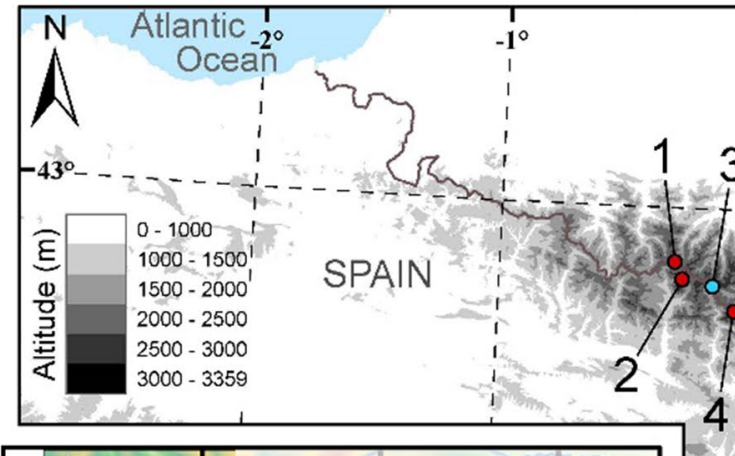

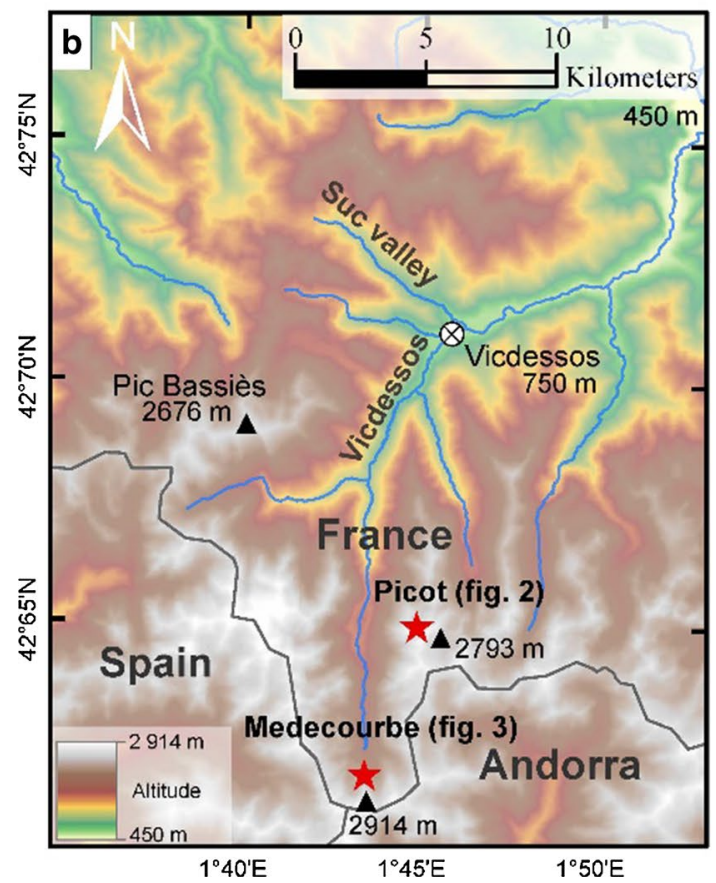

Fig. 1 General location of the studied area in Ariège region. a Pyrenean glaciers with accumulation areas above or below $3100 \mathrm{~m}$ altitude; 1: Baläitous; 2: Infierno, 3: Ossoue and Gaube, 4: Taillon, 5: Monte Perdido, 6: La Munia, 7: Poset, 8: Portillon, 9: Aneto and Mal- adeta, 10: Arcouzant. b Location of studied glacial cirques in the high Vicdessos valley. c Mean temperature and precipitation measurements at Vicdessos village between 1990 and 2011 
of the Pyrenees implies significant differences in climatic conditions with oceanic climatic conditions in the western and northern sectors of the range, and more continental and Mediterranean climate conditions in the southern and eastern sectors of the range. Today, glaciers are mostly present in the central part of the Pyrenees (Fig. 1) where mountain peaks reach a maximum altitude of about $3400 \mathrm{~m}$ above sea level (a.s.l.). However, geomorphic evidences demonstrate that glaciers occupied numerous valleys during the Late Glacial period on the northern and southern slopes of the range. The diverse climatic and topographic conditions may be responsible for specific glacier fluctuation at a local scale, for example, between the northern French Pyrenees and the southern Spanish slopes and at a regional scale between the Pyrenees and the Alps that have been more exhaustively studied.

To partly overcome this issue, several recent absolute Late Glacial and Holocene moraine chronologies have been published, mostly from the southern Spanish Pyrenees based on situ cosmic ray exposure (CRE) dating. On the eastern and central sectors of the mountain range, moraine dating revealed glacier stillstands or readvances at about $18 \mathrm{kyr}$. Glaciers occupied valley floors. They typically overcame $10 \mathrm{~km}$ in length, which remained nevertheless significantly shorter than their dimensions during the Last Glacial Maximum (LGM; Delmas 2015; Palacios et al. 2016a). From about $17 \mathrm{kyr}$ until approximately the beginning of the Younger Dryas (12.9-11.7 kyr; YD), glaciers retreated and abandoned the valley floors (Pallàs et al. 2006; Palacios et al. 2017). If climate conditions did not allow large glacier advances at that time, rather cold conditions favored the formation of numerous rock glaciers in many cirques or upper catchments (Palacios et al. 2015a, b, 2016a; Oliva et al. 2018). During the YD, glaciers expanded within the limits of the glacial cirques in both the central (Pallàs et al. 2006; Calvet et al. 2011; Delmas 2015; García-Ruiz et al. 2014, 2016a, b) and eastern Pyrenees (Pallàs et al. 2010; Crest et al. 2017). Many of the rock glaciers that had formed earlier remained active, and new ones formed during this period (Palacios et al. 2015a, b).

The glacial extent during the Holocene is poorly constrained due to limited dated moraines with some exceptions in the central Pyrenees (García-Ruiz et al. 2014). During the Little Ice Age (LIA, CE 1350-1850; Solomina et al. 2015), historical documents and few CRE dating attest that glaciers were relatively small and restricted to high peaks, but were still larger than today, at least in the Central Pyrenees on both northern and southern slopes (González Trueba et al. 2008; Oliva et al. 2018). This LIA extent on the southern slopes of the Central Pyrenean cirques may correspond to the maximum glacier advance during the Holocene (Palacios et al. 2017) as recently documented in the Maladeta massif (Crest et al. 2017). This contrasts with several places in the
Alps (Schimmelpfennig et al. 2012, 2014; Solomina et al. 2015; Protin et al. 2019) where an early Holocene period leads to observed glacier advance larger than that of the LIA.

Similarly, high-altitude climatic conditions responsible for such glacier fluctuations during the Late Glacial and Holocene remain still poorly constrained, mostly because climate reconstructions in this region are rare. In the west-central French Pyrenees, a reconstruction for July air temperatures from chironomid head capsules was proposed from a sediment core retrieved from the Ech paleolake (710 m a.s.1.) (Millet et al. 2012). Between 19 and $15 \mathrm{kyr}$, summer temperature oscillated between $7^{\circ}$ and $4{ }^{\circ} \mathrm{C}$ cooler than today. From 14.8 to $12.9 \mathrm{kyr}$, a brutal increase in temperature of about $5{ }^{\circ} \mathrm{C}$ (compared to the earlier period) was recorded. During the YD, inferred temperatures decreased by $2{ }^{\circ} \mathrm{C}$ compared with the current values reached at the beginning of the Holocene. Multi-proxy paleoclimatic reconstructions with robust age control derived from lacustrine, dendrochronological and geomorphological records support warm and relatively arid conditions during the Medieval Climate Anomaly (MCA, CE 900-1250; Morellon et al. 2012; Oliva et al. 2018). The LIA was generally about $1{ }^{\circ} \mathrm{C}$ cooler than today and moister than the MCA. In addition, a multi-proxy study of high-altitude lake sediments from the French Pyrenees in the Ariège region (Lake Majeur draining Pic Bassies, cf Fig. 1) also documents a MCA interrupted by several humid periods (dated at CE 940, 1080, 1100 and 1250) and the onset of a more humid LIA after CE 1500 (Simonneau et al. 2013b).

To contribute to a better understanding of glacier fluctuations in the French Pyrenees, Late Glacial and Holocene fluctuations of two cirque glaciers on the northern slope of the Pyrenees in the Ariège region were dated using the CRE dating method. The second objective of this paper was to estimate climate conditions responsible for such glacier fluctuations. To this end, our approach consisted of using a glaciological model to retrieve paleoglacier extents, equilibrium line altitude (ELA) changes and their associated climatic conditions. These simulated paleoglacier fluctuations were constrained by the absolute CRE dating of the moraine records.

\section{Study area}

The two glacial cirques selected in this study are located in the upper Ariège valley (French Pyrenees), about $18 \mathrm{~km}$ south from Vicdessos village, in the high Vicdessos valley (Fig. 1). The first glacial cirque forms a small north-south elongated catchment at the foot of the northern face of Pic de Médécourbe (2914 m a.s.1., $42.61^{\circ} \mathrm{N} ; 1.44^{\circ} \mathrm{E}$ ) which constitutes a natural border between Spain and Andorra (Fig. 1). The catchment area $\left(1.2 \mathrm{~km}^{2}\right)$ is composed of 
Cambrian mica schist and granite. The Médécourbe north face is constituted by a main vertical granite cliff of about $500 \mathrm{~m}$ height, with several secondary pillars and shoulders (Fig. 2). The maximum altitude of the catchment is currently below the regional ELA which is above $3100 \mathrm{~m}$ (Chueca et al. 2007; René 2011), meaning that the catchment does not have any accumulation area. However, at the base of the cliff, a small permanent snow patch (about $150 \mathrm{~m}$ long) is still preserved, probably due to the shadow effect of the cliff and frequent snow avalanches that favor exceeding snow accumulation. Downslope, about $1.4 \mathrm{~km}$ from this snow patch, a proglacial lake was formed behind three nested frontal moraines (Fig. 2).
The second glacial cirque Picot is a steep-walled amphitheater composed of three glacially carved hollows separated by sub-vertical rock cliffs about $100 \mathrm{~m}$ high that favored the formation of four shallow lakes (Fig. 3). These depressions delimit three sub-catchments currently without any glacier or ice-snow patch (Figs. 1, 3, 6). As for Médécourbe catchment, the highest sub-catchment has a maximum altitude lower than the current regional ELA. Two of these sub-catchments are covered by large rock glaciers. The first one is close to the summit (just upstream of Lake 4), at about $2500 \mathrm{~m}$ a.s.1. A smaller one is located close to the lowest lake (Lake 1), at about $2050 \mathrm{~m}$ a.s.1. (Fig. 3).

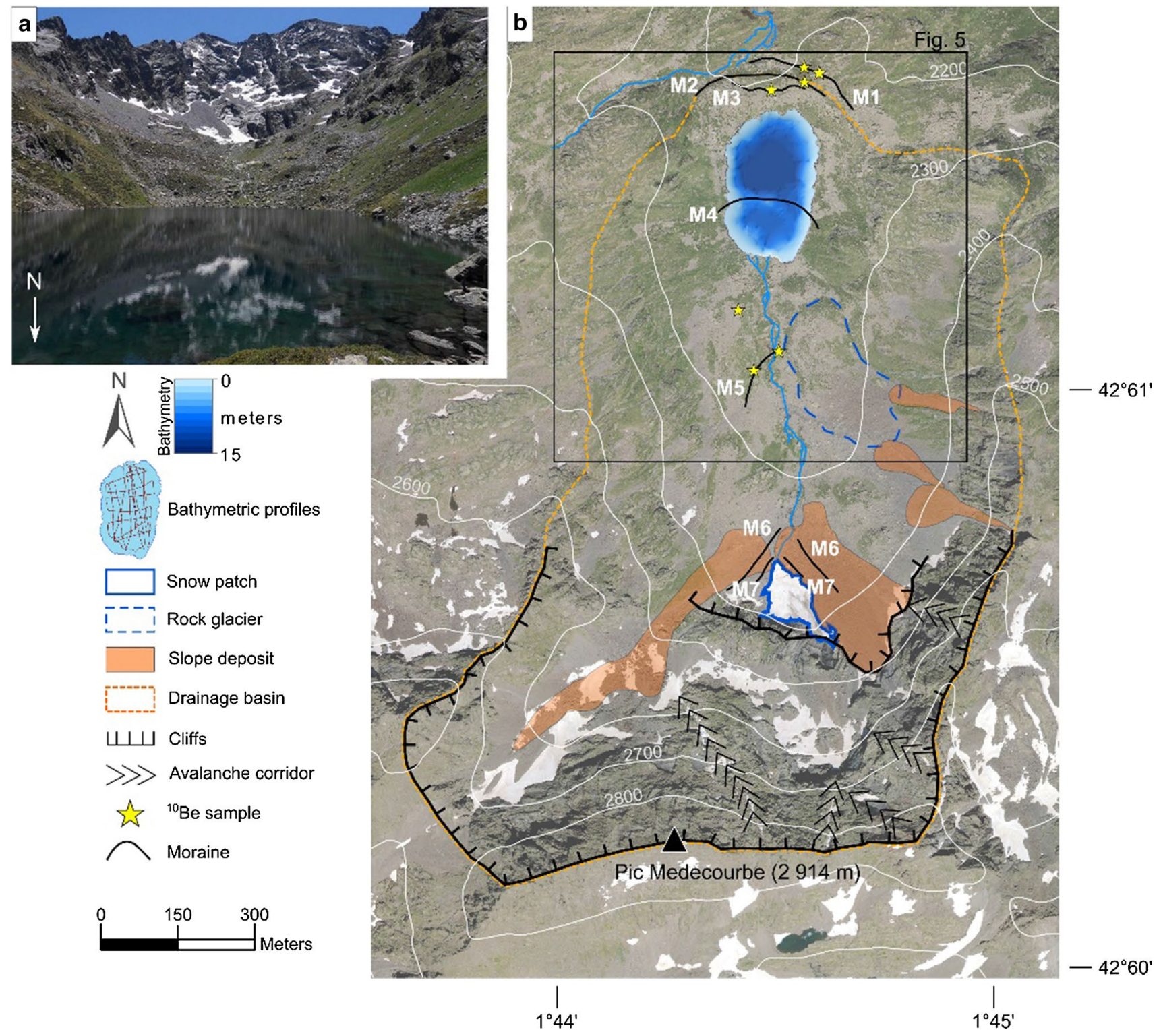

Fig. 2 Médécourbe catchment. a Photography of the catchment from the Médécourbe lake. b Geomorphological map and bathymetry of the lake. The location of Fig. 5 is also indicated 

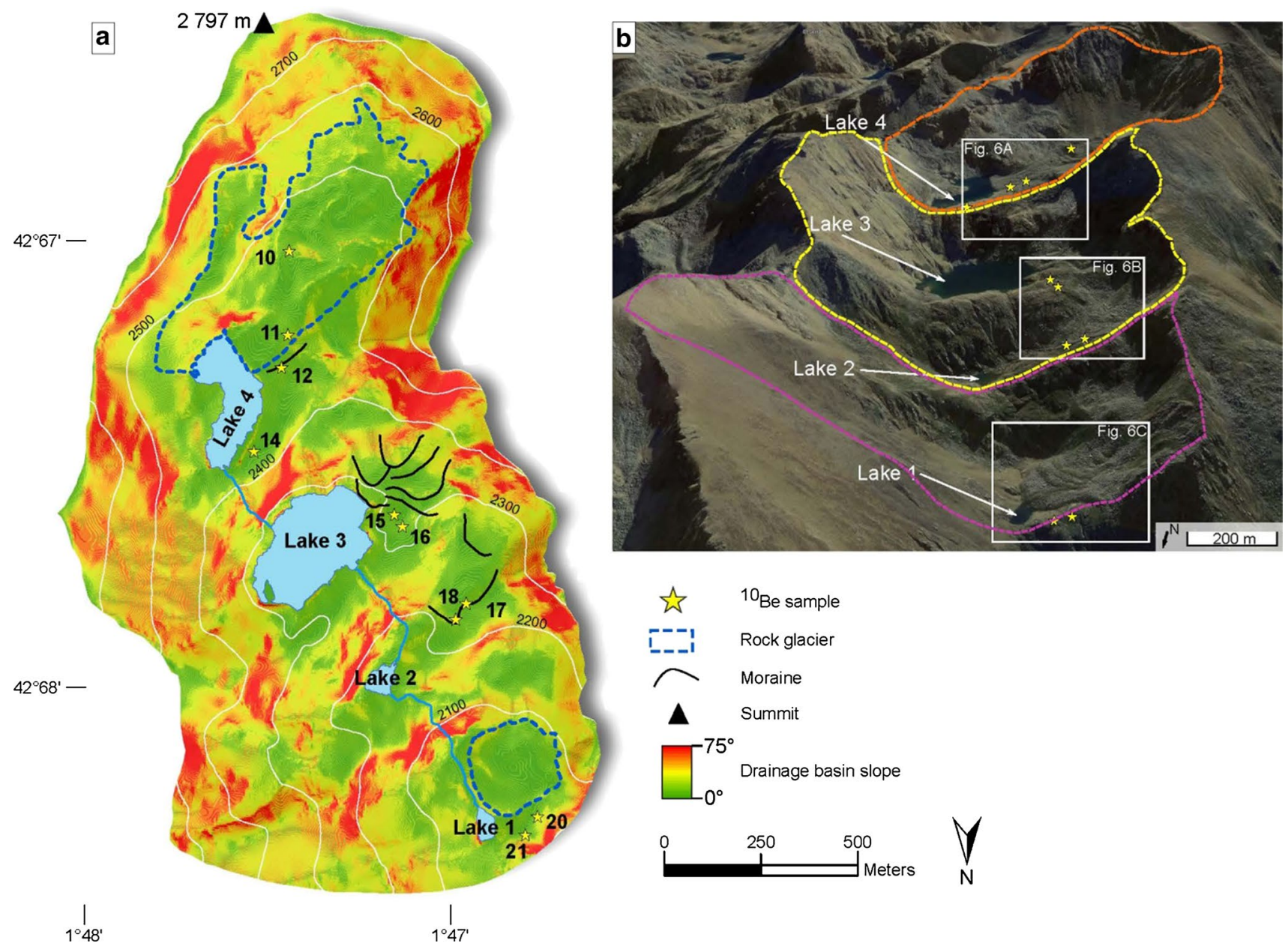

Fig. 3 Picot catchment. a Slope map of sub-catchments locating lakes, moraines and rock glaciers; b Google Earth image showing the three subcatchments with the sample locations and the location of Fig. 6a-c

Climate conditions in upper Ariège valley (Fig. 1) are subject to Atlantic disturbances from the northwest, with maximum rainfall in spring and winter (Jalut et al. 1982). In this region, intense summer storms are frequent but significant winter snow falls are providing a nival regime to the Vicdessos River (Simonneau et al. 2012; Gascoin et al. 2015; Szczypta et al. 2015; Marti et al. 2016). In the Vicdessos valley, meteorological observations at Auzat (750 m altitude) showed a mean annual temperature of $11{ }^{\circ} \mathrm{C}$ and mean precipitation of $1200 \mathrm{~mm} /$ year between 1990 and 2011 (Fig. 1). In Gavarnie valley, near Ossoue Glacier (Fig. 1), the mean annual temperature was about $7.6^{\circ} \mathrm{C}$ at $1310 \mathrm{~m}$ and precipitation varied between 770 and $1550 \mathrm{~mm}$ per year (2000-2011), of which at least 30\% felt as snow above $1600 \mathrm{~m}$ altitude between November and June (Marti et al. 2016).

\section{Methods}

\section{Field sampling}

Geomorphological mapping of the moraines and glacial features in the upper Ariege valley was conducted using aerial pictures from 2013 as well as field observations in 2016. Samples for ${ }^{10} \mathrm{Be}$ CRE dating of boulders were taken on roches moutonnées, moraines and rock glaciers to determine the chronology of glacier fluctuations. Médécourbe lake bathymetric map was documented in summer 2013 using a conventional GPS and digitalized $14 \mathrm{kHz}$ and $200 \mathrm{kHz}$ sub-bottom profiles (Knudsen portable device) collected from an inflatable boat. Mapping Médécourbe lake bathymetry from sub-bottom profiles was realized using the EDIFISegy software (allowing for the production of a shapefile from each profile). Each shapefile was 
then integrated within a GIS to plot the lake isobaths and to combine it with a geomorphological map of the drainage basin (Fig. 2).

All ${ }^{10} \mathrm{Be}$ samples were collected with a manual hammer and chisel in summer 2016 from the horizontal to sub-horizontal uppermost surfaces of large boulders ( $>60 \mathrm{~cm} \mathrm{high).}$ The boulders were stable and without evidence of loss due to denudation processes. Sample locations and elevations were recorded using a handheld GPS, and topographic shielding (horizon line) was measured using a clinometer and a compass (Table 1).

\section{Laboratory analysis and CRE age calculation}

${ }^{10} \mathrm{Be}$ samples were processed at CALM lab (Cosmonucléides Au Laboratoire de Meudon-France). In situ-produced ${ }^{10} \mathrm{Be}$ was measured in the quartz mineral fraction separated from the rock samples. Samples were crushed and sieved (250-750 $\mu \mathrm{m})$; magnetic components were eliminated using a Frantz magnetic separator. Quartz was extracted by dissolution of undesirable minerals in $\mathrm{HF} / \mathrm{HNO}_{3}$ acid mixture and atmospheric ${ }^{10} \mathrm{Be}$ removed through sequential dissolution $(\sim 10 \%$ in mass) in diluted HF. The obtained pure quartz was spiked with $500 \mu \mathrm{l}$ of a commercial standard solution from the Scharlau Company (1000 $\mathrm{mg} \mathrm{l}^{-1}$ of $\mathrm{BeO}$ ) and then digested in $48 \%$ hydrofluoric acid. Beryllium was extracted by column chromatography using anion and cation exchange resins and alkaline precipitation. The obtained beryllium hydroxides were dried and finally oxidized for $1 \mathrm{~h}$ at $900{ }^{\circ} \mathrm{C}$. The final $\mathrm{BeO}$ oxides were mixed with niobium powder for AMS measurements at the French 5 MV AMS national facility ASTER (Aix-en-Provence) (Klein et al. 2008; Arnold et al. 2010). Measurements were calibrated against the in-house standard STD-11 with an assigned ${ }^{10} \mathrm{Be} /{ }^{9} \mathrm{Be}$ ratio of $1.191 \pm 0.013 \times 10^{-11}$ (Braucher et al. 2015) using a ${ }^{10} \mathrm{Be}$ half-life of $1.387 \pm 0.0012 \times 10^{6}$ years (Chmeleff et al. 2010). Topographic shielding was calculated using Cronus Earth online calculator. ${ }^{10} \mathrm{Be}$ ages were calculated using the CREP online calculator (Martin et al. 2017; https ://crep.otelo.univ-lorraine.fr/\#/) applying the Lal-Stone time-corrected scaling scheme (Lal 1991; Stone 2000), the ERA 40 atmosphere model and the atmospheric ${ }^{10} \mathrm{Be}$-based VDM for geomagnetic data base, and using the European production rate (Claude et al. 2014; 4.16 \pm 0.2 ). Applying one of the two other production rates "Nena" (Balco et al. 2009) or "Arctic" (Young et al. 2013) would lead to ages younger by about $5 \%$. We did not make corrections for snow cover and denudation of the boulder surface. In the main text and figures, we report individual $\mathrm{CRE}{ }^{10} \mathrm{Be}$ ages with their associated uncertainties that include the standard deviations of both analytical (reported Table 1) and production rate uncertainties. For a given moraine, its age corresponds to the arithmetic mean of the sample ages from that moraine that has to successfully pass a Chi-square test (Ward and Wilson 1978) used to identify outliers. We also considered the stratigraphic relationships to identify outliers.

\section{The glaciological model}

A glaciological mass balance model combined with a simple ice flow dynamic model was used to invert the paleoclimate conditions responsible for stillstands or advances documented from CRE dating on well-preserved moraines. To do so, a model based on the well-established relationships between climate data and mass balance named the positive degree day (PDD) model (Braithwaite 1985, 1995) was applied. The model is described in detail in Jomelli et al. (2011) and was successfully applied in different regions around the world to reconstruct former glacier-climate states (Blard et al. 2007; Jomelli et al. 2011, 2016; Biette et al. 2018). It provides a process-based approach considering detailed data on the relationship between glacier ablation and air temperature from modern glaciers. The PDD model was run to estimate equilibrium line altitude (ELA) and mass balance changes for the distinct paleoglacial extents documented in the field by moraine positions. It is based upon the notion that glacier melting occurs when air temperature 1-2 $\mathrm{m}$ above the glacier surface is above the melting point $\left(0{ }^{\circ} \mathrm{C}\right)$. The total melt over a period of time at some point on the glacier is therefore proportional to the sum of positive temperatures at the same point, i.e., the positive degree day total.

\section{Glaciological model validation}

The PDD model was first tested and calibrated on the Ossoue Glacier $\left(42^{\circ} 61^{\prime} \mathrm{N} ; 1^{\circ} 44^{\prime} \mathrm{E}\right)$, in the French Pyrenees, where 16 years of surface mass balance data have been collected (Marti et al. 2015). This glacier has been recently added to the French glacier observatory-GLACIOCLIM. The model was applied using the mean degree day factor for snow $\left(3.0 \mathrm{~mm}\right.$ w.e. $\left.{ }^{\circ} \mathrm{C}^{-1} \mathrm{day}^{-1}\right)$ and for ice $(6.1 \mathrm{~mm}$ w.e. ${ }^{\circ} \mathrm{C}^{-1}$ day $^{-1}$ ) proposed over Alpine melting rates (Six and Vincent 2014). Relying on current climate conditions observed at the Gavarnie meteorological station (1310 $\mathrm{m}$ a.s.1.), the PDD model was applied to the Ossoue glacier (between 2870 and $3140 \mathrm{~m}$ a.s.1.) using observed temperature lapse rates and precipitation gradients. For the temperature, Navarro-Serrano et al. (2018) proposed different lapse rates according to valley orientations in the Spanish Pyrenees. For a glacier oriented eastward, they proposed a lapse rate of $5.2{ }^{\circ} \mathrm{C} / 1000 \mathrm{~m}$. According to Marti et al. (2015), the orographic effect on precipitation is significant in the Ossoue glacier area, and precipitation value from the Gavarnie station needs to be multiplied by 2.8 to reach the values 


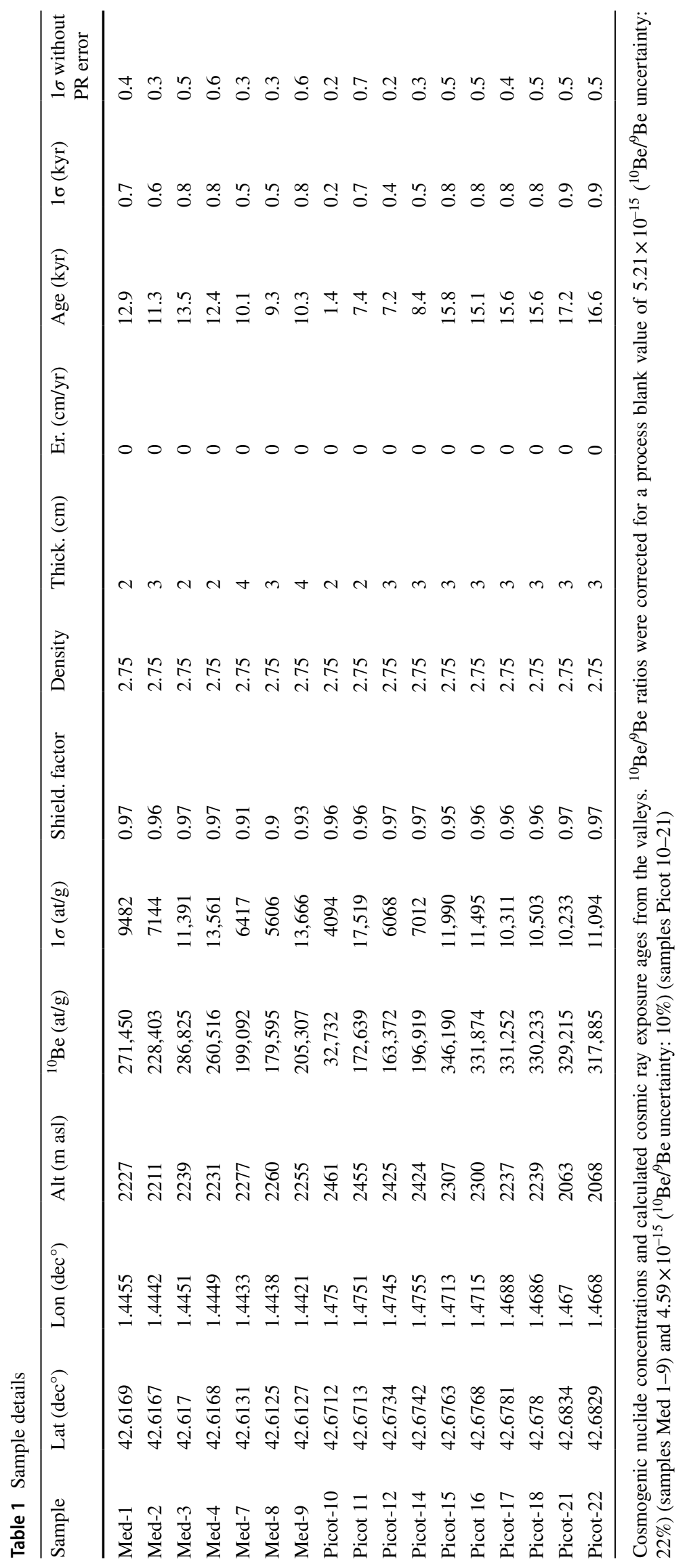


observed on the glaciers (Marti 2016). Consequently, a linear precipitation increase with altitude between the Gavarnie station and the glacier (at $2800 \mathrm{~m}$ a.s.1.) was introduced. The computed surface mass balance is in agreement with observations recorded between 2000 and 2016, suggesting that the model is in agreement with glaciological processes at this location (Fig. 4).

Using similar calibrations, but slightly larger precipitations than over the Ossoue glacier (perhaps due to overaccumulation caused by avalanches), we verified that the PDD modeling was in good agreement with surface mass balance (SMB) measurements on the Maladeta glacier over

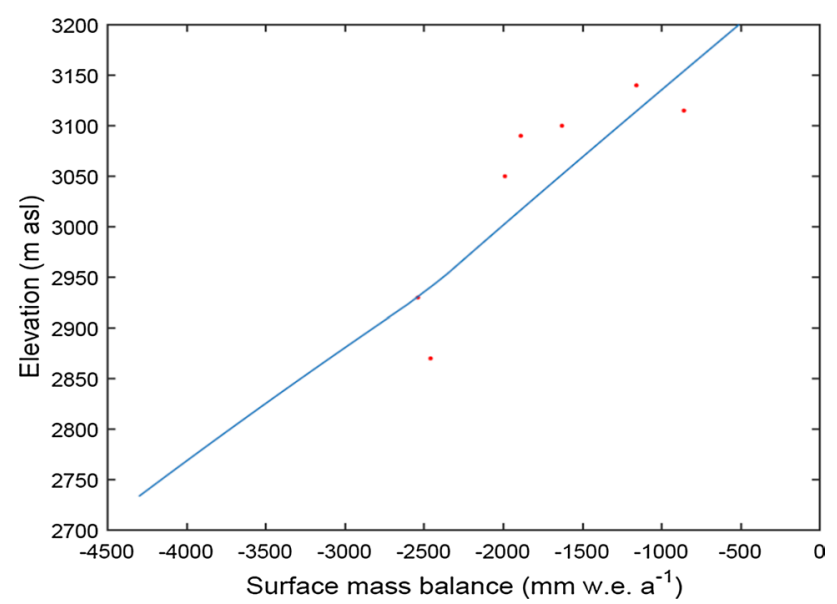

Fig. 4 PDD model results (blue line) versus mass balance measurements (red dots) for the Ossoue Glacier (calibration step) the 2000-2016 period (not shown). The model was therefore applied over Médécourbe and Picot areas using a precipitation gradient with respect to the altitude similar to that of the Ossoue glacier. However, the temperature lapse rate was estimated to be $5.8^{\circ} \mathrm{C} / 1000 \mathrm{~m}$ for the Médécourbe and Picot valleys that are oriented to the North (Navarro-Serrano et al. 2018).

\section{Results}

\section{Médécourbe moraine chronology}

Seven new CRE ${ }^{10} \mathrm{Be}$ ages from the four Médécourbe moraines have been acquired (Table 1; Figs. 2, 5). For convenience, these moraines were labeled from the oldest M1 to the youngest M5. The large rampart on the external side of Médécourbe Lake, at about 2200 m a.s.l., was first investigated. It forms a massive arcuate landscape $60 \mathrm{~m}$ long and $10 \mathrm{~m}$ high, located about $1.4 \mathrm{~km}$ downslope from the present snow patch (Fig. 5). This massive landform is composed of at least three nested moraines labeled M1 to M3. The first two samples (Med-1 and Med-3) were collected on the external ridge M1 to document the oldest stage of the Médécourbe paleoglacier located in the upper part of the valley. These two samples yield $\mathrm{CRE}{ }^{10} \mathrm{Be}$ ages ranging from $12.9 \pm 0.7$ to $13.5 \pm 0.8 \mathrm{kyr}$ that lead to an average CRE age of $13.2 \pm 0.3 \mathrm{kyr}$. Med-4, collected on M2, a clearly distinguishable ridge in between $\mathrm{M} 1$ and $\mathrm{M} 3$, yields a ${ }^{10} \mathrm{Be}$ CRE age of $12.4 \pm 0.8 \mathrm{kyr}$. Sample Med-2, located
Fig. $5 \mathrm{CRE}{ }^{10} \mathrm{Be}$ ages given in kyr at Médécourbe site. The $1 \sigma$ uncertainties for individual ${ }^{10} \mathrm{Be}$ boulder ages account for analytical and production rate uncertainties. The colors refer to landforms discussed in the text

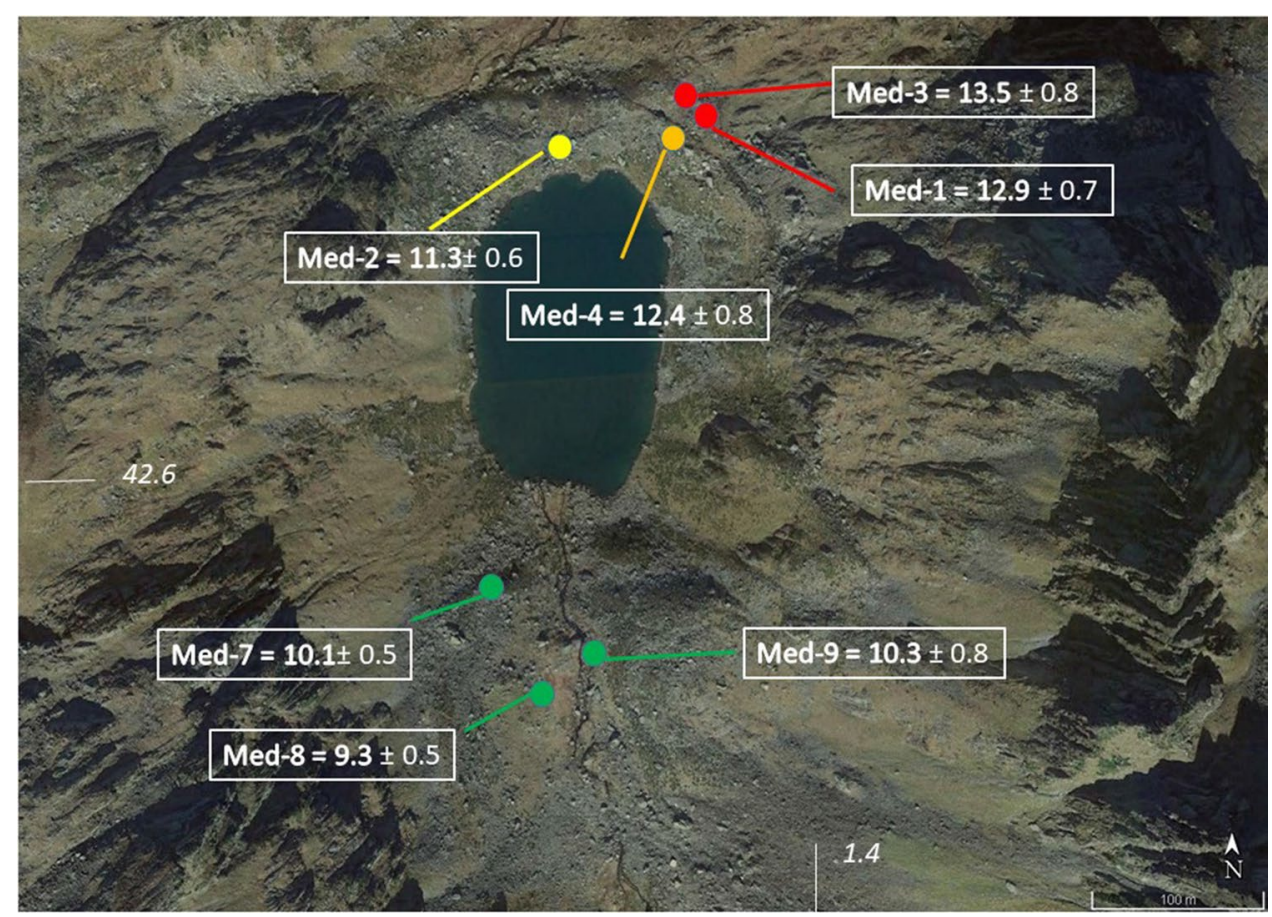


on M3, a small arcuate ridge on the most internal side of the landform, yields a CRE ${ }^{10} \mathrm{Be}$ age of $11.3 \pm 0.6$. As the internal uncertainties of the different samples overlap and thus belong to the same population, the age of this rampart was calculated. The Med $1-4$ group yields a mean ${ }^{10} \mathrm{Be} \mathrm{CRE}$ age of $12.4 \pm 0.4 \mathrm{kyr}$ (considering the full uncertainties but $12.9 \pm 0.4 \mathrm{kyr}$ considering the analytic uncertainty only, $n=3$ as Med 2 is then identified as an outlier). Hence, this rampart is assumed to have been emplaced during the Late Glacial-YD transition. The bathymetric map of Médécourbe lake, based on a dense grid of sub-bottom profiles, evidences another moraine (labeled M4) whose frontal part in the middle of the lake splits the bottom of the lake into two subbasins (Fig. 2). A lateral remain of this moraine extends only on the western side, close to the rock cliff. Because of its proximity to the surrounding cliffs, this moraine remains are exposed to rock falls and snow avalanches, and was therefore not sampled for CRE dating purpose. On the eastern side of the valley, the moraine M4 is covered by a large rock glacier. Three other moraines are also visible between the lake and the snow patch. The lowest one (labeled M5) was sampled, while the two upper ones were not because of their proximity to the surrounding cliffs and the presence of perched boulders evidencing snow avalanche deposits (Jomelli and Bertran 2001). Med-7 collected on a roche moutonnée in between the lake and M5 yields a CRE ${ }^{10} \mathrm{Be}$ age of
$10.1 \pm 0.5$ kyr. Samples Med-8 and Med-9 were selected on the small moraine (M5) remains and yield CRE ${ }^{10} \mathrm{Be}$ ages of $9.3 \pm 0.5 \mathrm{kyr}$ and $10.3 \pm 0.8 \mathrm{kyr}$, respectively (mean age $9.6 \pm 0.4 \mathrm{kyr}, n=2)$.

\section{Picot moraine chronology}

The fluctuations of the Picot paleoglacier are deduced from ten ${ }^{10} \mathrm{Be} \mathrm{CRE}$ ages of samples (Figs. 3, 6; Table 1) taken from the lowest moraine located at $2060 \mathrm{~m}$ to those at the head of the valley at $2500 \mathrm{~m}$ in the different suspended sub-basins. Cosmic ray exposure ${ }^{10} \mathrm{Be}$ ages range from $17.2 \pm 0.9$ to $1.4 \pm 0.2$ kyr. Four ${ }^{10} \mathrm{Be}$ samples (Picot-17, $18,21,22)$ were collected from boulders located on two moraines, named from the oldest M1 to the youngest M2, that were deposited at the base of the second and third crag at $2060 \mathrm{~m}$ and $2230 \mathrm{~m}$ a.s.l., respectively. Picot- 21 and $-22(17.2 \pm 0.9 \mathrm{kyr}$ and $16.6 \pm 0.9 \mathrm{kyr}$, respectively) were collected on a frontal moraine (M1) deposited at $2060 \mathrm{~m}$ a.s.l., at the base of the lowest lake. These samples yield a mean $\mathrm{CRE}{ }^{10} \mathrm{Be}$ age of $16.9 \pm 0.6 \mathrm{kyr}$ for this frontal moraine. Picot-17 and -18 located on the left side of the lateral moraine $\mathrm{M} 2$ in the second sub-catchment provided two identical CRE ${ }^{10} \mathrm{Be}$ ages of $15.8 \pm 0.6 \mathrm{kyr}$. Two other erratics (Picot-15-16) were collected at higher altitude (2300 and

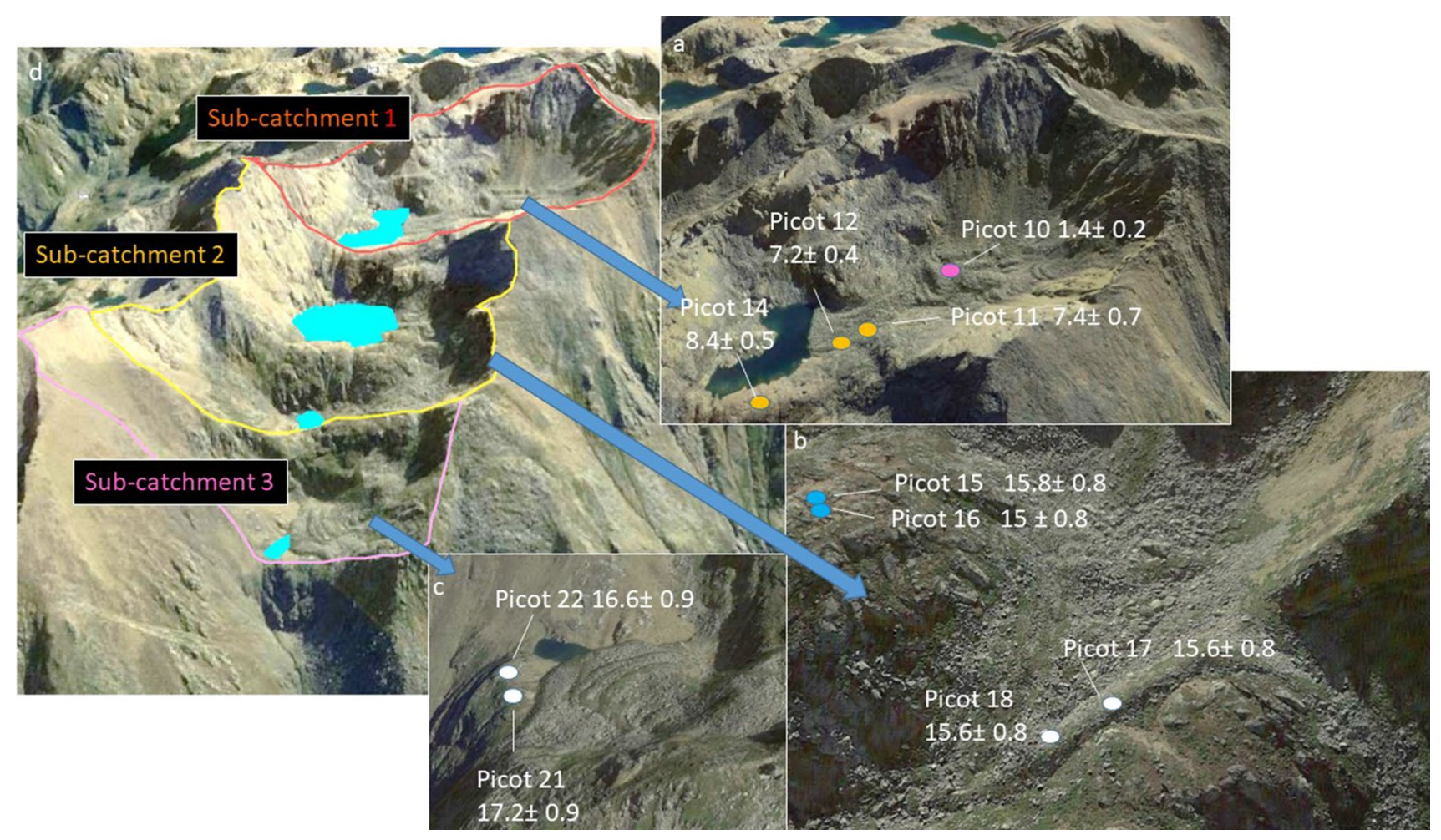

Fig. 6 a-d ${ }^{10} \mathrm{Be}$ CRE ages given in kyr in the Picot catchment. The $1 \sigma$ uncertainties associated with individual boulder ${ }^{10} \mathrm{Be} \mathrm{CRE}$ ages account for analytical and production rate uncertainties. The colors refer to landforms discussed in the text 
$2307 \mathrm{~m}$ a.s.l., respectively) on a roche moutonnée in subcatchment 2 . Their $\mathrm{CRE}{ }^{10} \mathrm{Be}$ ages are $15.8 \pm 0.8 \mathrm{kyr}$ and $15.0 \pm 0.8 \mathrm{kyr}$ (Picot-15-16), respectively, and constrain the glacial retreat rate in the upper part of the valley. Another sample, Picot-14, was sampled at $2424 \mathrm{~m}$ a.s.l., on a roche moutonnée that borders sub-catchments 1 and 2. It yields a CRE ${ }^{10} \mathrm{Be}$ age of $8.4 \pm 0.5 \mathrm{kyr}$. Finally, in the highest subcatchment, three samples (Picot-10, -11 and -12) were collected on ridges of a rock glacier (Fig. 6). Picot-10, whose $\mathrm{CRE}{ }^{10} \mathrm{Be}$ age is $1.4 \pm 0.2 \mathrm{kyr}$, was collected on the highest upslope internal ridge. The two other boulders were sampled on the external ridge of the rock glacier far from the rock cliff to avoid the selection of boulders resulting from recent rockfall activity, and slightly away from the front, to avoid instability from the cirque headwalls. They yield consistent CRE ${ }^{10} \mathrm{Be}$ ages of $7.4 \pm 0.7 \mathrm{kyr}$ and $7.2 \pm 0.4 \mathrm{kyr}$, the mean $\mathrm{CRE}{ }^{10} \mathrm{Be}$ age being $7.2 \pm 0.3 \mathrm{kyr}$.

\section{Estimation of climatic conditions responsible for Picot and Médécourbe glacial extents during HS1 and Late Glacial- YD transition periods}

The PDD modeling approach was applied to estimate climate conditions that are consistent both with the Late Glacial extent at $16.9 \pm 0.6 \mathrm{kyr}$ for the Picot glacier at $2060 \mathrm{~m}$ a.s.l. and with the Late Glacial-YD transition extent at $12.4 \pm 0.4 \mathrm{kyr}$ for the Médécourbe glacier at $2200 \mathrm{~m}$. Both periods were documented with their respective frontal moraines. The PDD model provides ELA and mass balance changes for these two distinct paleoglacial extents and potential combinations of precipitation and temperature changes that are consistent with these mass balance changes.

Results show that temperature about $5.1{ }^{\circ} \mathrm{C}$ cooler than today with precipitation rates similar to the current ones would be necessary to get an ELA at $2473 \mathrm{~m}$ and a moraine at the base of the Picot catchment (2060 m a.s.l.) during HS1, that is at about $16.9 \pm 0.6 \mathrm{kyr}$ (Fig. 7). The PDD models also suggests temperature $3.9^{\circ} \mathrm{C}$ cooler than today with again no change of precipitation amount to explain an ELA at $2543 \mathrm{~m}$ and a moraine deposited at $2200 \mathrm{~m}$ during the Late Glacial-YD transition at Médécourbe.

\section{Discussion}

The data from Picot and Médécourbe valleys address questions about the Late Glacial and Holocene climatic conditions and related glacier extents in northeastern Pyrenees. We first examine the two glacier chronologies. These two small glacial valleys located close to each other and at an altitude lower than $3000 \mathrm{~m}$ a.s.l., on the northern slope of the

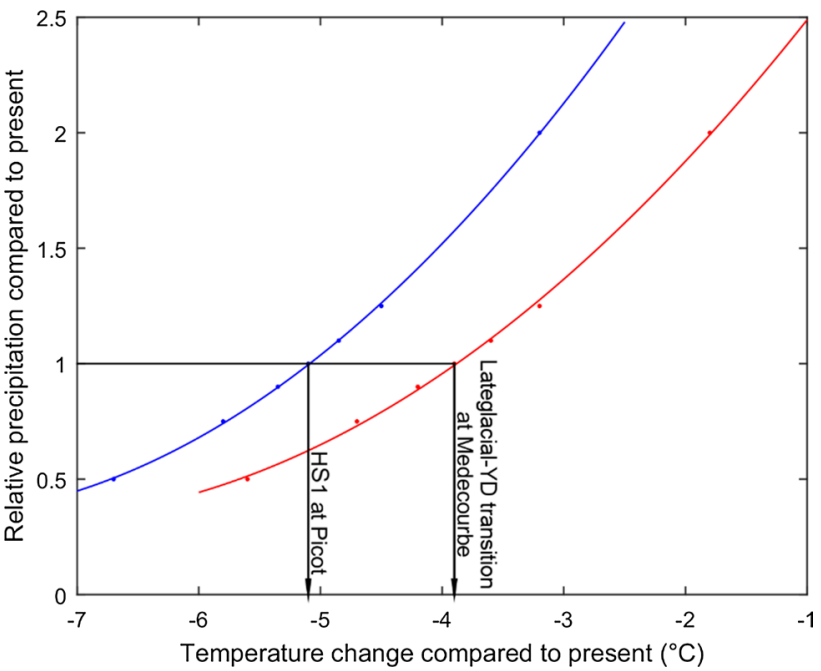

Fig. 7 Paleoclimatic conditions at $2060 \mathrm{~m}$ a.s.l. and $2200 \mathrm{~m}$ a.s.1. required to reproduce the Picot glacier extent over the past $16.9 \mathrm{kyr}$ (blue curve) and the Médécourbe glacier during the Late Glacial-YD transition (red curve), respectively. Changes in precipitation are plotted against changes in temperature $(\Delta T) . Y$-axis: relative precipitation normalized to present day value at about $2060 \mathrm{~m}$ and $2200 \mathrm{~m}$ a.s.1

Pyrenees range reveal distinct glacial dynamics at the millennial time scale, possibly related to the different morphometric catchment characteristics. In the Picot valley, glacier advances during the Late Glacial were the largest, while large moraines formed during the Holocene, in particular during the LIA, are missing, if one refers to the evolution documented in the Alps or in some Pyrenean valleys (Solomina et al. 2015; Oliva et al. 2018). The ${ }^{10} \mathrm{Be}$ CRE ages from boulders on roche moutonnées and moraines suggest that the glacier was already confined to the upper part of the valley from about $17 \mathrm{kyr}$ onwards, as shown by the mean ${ }^{10} \mathrm{Be}$ CRE age of moraine M1 at $2060 \mathrm{~m}$ a.s.l. Sub-catchment 3 was probably free of ice from about $16 \mathrm{kyr}$ ago, based on ${ }^{10} \mathrm{Be} \mathrm{CRE}$ ages of the lateral moraine located at about $2230 \mathrm{~m}$ a.s.l in the sub-catchment 2. Sub-catchment 2 may have been already partly deglaciated at about $15.6 \mathrm{kyr}$ ago, as there is no clear evidence of moraine on the right side of the valley. Sub-catchment 3 was likely free of ice during the early Holocene based on the ${ }^{10} \mathrm{Be}$ CRE age of the erratic boulder Picot-14 dated at about 8.4 kyr. Here again, no evidence of moraine on the right side of the catchment that may have been emplaced during the YD or the early Holocene period. In this valley, two large rock glaciers developed. The highest one located at $2450 \mathrm{~m}$ a.s.l. may have stabilized at 6-7 kyr during the Holocene Climate Optimum, when warmer conditions must have conditioned permafrost thawing as suggested in other places (Pallàs et al. 2006; Palacios et al. 2016b). A possible reactivation of this landform during the late Holocene period may explain the formation of the upper ridge on which Picot-10 sample was collected. The 
age formation of the lowest rock glacier in sub-catchment 3 is not constrained. We suspect that it may have been formed at the end of HS1 or during younger periods.

In the Médécourbe valley, the investigated moraine landforms M1-M3 are located at the same altitude as sub-catchment 2 in the Picot valley. Even if the age of the moraines M1-M3 dated either to the YD or a little earlier according to the selected hypothesis (either grouping ages from the different ridges or only M1) is questionable, we did not find any moraine landforms formed during the HS1 event. If they existed, they were either located at a lower altitude but mostly eroded (as clear and large moraine remains are not easily distinguishable in the field) or located at the same altitude but recovered since by the younger glacier advance responsible for the formation of moraine M1. The reasons why these Late Glacial-YD moraines (M1-M3) were found in the Médécourbe valley only remain unclear. It may be due to the flat topography that favored moraine preservation compared to hanging valleys in the Picot catchment. It may also be due to local effects that would favor high snow accumulation caused by snow avalanches and/or shadow effects, which in addition could explain the current presence of a snow patch in this catchment. Interestingly, such local effect may also be relevant to explain a minor advance or stillstand during the early Holocene, as revealed by remains of moraines dated at around $9 \mathrm{kyr}$. We also cannot exclude the possibility of a glacier advance during the late Holocene or during the LIA that may have formed the moraine remains identified in the field between the current snow patch and the early Holocene moraine remains, but that are undated. However, if a glacier advance during the late Holocene existed in the catchment, it did not create a large advance that exceeded those that occurred during the early Holocene.

Second, the climatic conditions that may be responsible for the glacier dynamics in our study area were examined. From the Late Glacial to the late Holocene, important changes in climatic conditions occurred in the North Atlantic region (Ramussen et al. 2007) with several abrupt temperature changes exceeding $3-5^{\circ} \mathrm{C}$. In the Alps, temperature reconstructions uniformly display a rapid warming in summer temperature of about $2-3{ }^{\circ} \mathrm{C}$ between the Late Glacial and the YD (Heiri et al. 2003, 2014; Heiri and Millet 2005; Lotter et al. 2012). A warming of between 1.5 and $4{ }^{\circ} \mathrm{C}$ was also recorded during the YD-early Holocene transition (Heiri et al. 2014; Solomina et al. 2015). Estimated changes in mean July air temperature at $2000 \mathrm{~m}$ a.s.l. inferred from past maximum and minimum elevations of treeline in the Bernese region suggested a warming of about $6{ }^{\circ} \mathrm{C}$ from the Late Glacial to the early Holocene (15-8 kyr) (Heiri et al. 2014). Assuming that the precipitations were similar to today, to form a frontal moraine at 2060 and $2200 \mathrm{~m}$ a.s.l. in Picot and Médécourbe valleys, respectively, the PDD approach applied to these Ariège glaciers suggests temperature between 5.1 and $3.9^{\circ} \mathrm{C}$ cooler than today during the HS1 and the Late Glacial-YD transition. Such temperature estimation in the Ariège region is conform to independent temperature records mentioned above. Interestingly, such estimation of temperature change also conforms to the one estimated from chironomid head capsules in the Ech paleolake at $710 \mathrm{~m}$ a.s.l. proposed by Millet et al. (2012). The absence of moraine during the late Holocene in Picot valley suggests that ELA may have been already higher than the upper part of the catchment at least around $8 \mathrm{kyr}$ ago, possibly due to an increase in temperature limiting glacier regeneration. Moreover, the temperature did not decrease enough during the late Holocene to drop the ELA and generate new glacier advances in this region.

The comparison of our glacier records with that published in other valleys of the Pyrenees leads to notice that a distinction has to be made between high- and low-altitude catchments currently containing (or not) an accumulation area (considering current ELA) (Figs. 1, 8; Table 2). We indeed suspect that the size of the accumulation area partly controlled by the altitude of the catchment is an important parameter potentially allowing to explain the glacier dynamics at a regional scale. This leads to the hypothesis that relics of Holocene moraines may be present in high-altitude catchments, while they are generally absent in low-altitude catchments. This elevation parameter appears more significant than the orientation of the Pyrenees range (northern versus southern slope). Glacier behavior in Médécourbe may be viewed as an intermediate case between the low- and highaltitude catchments of the Pyrenees that will be discussed afterwards. ${ }^{10} \mathrm{Be} \mathrm{CRE}$ ages from Picot are consistent with the general deglaciation trend documented in other low-altitude

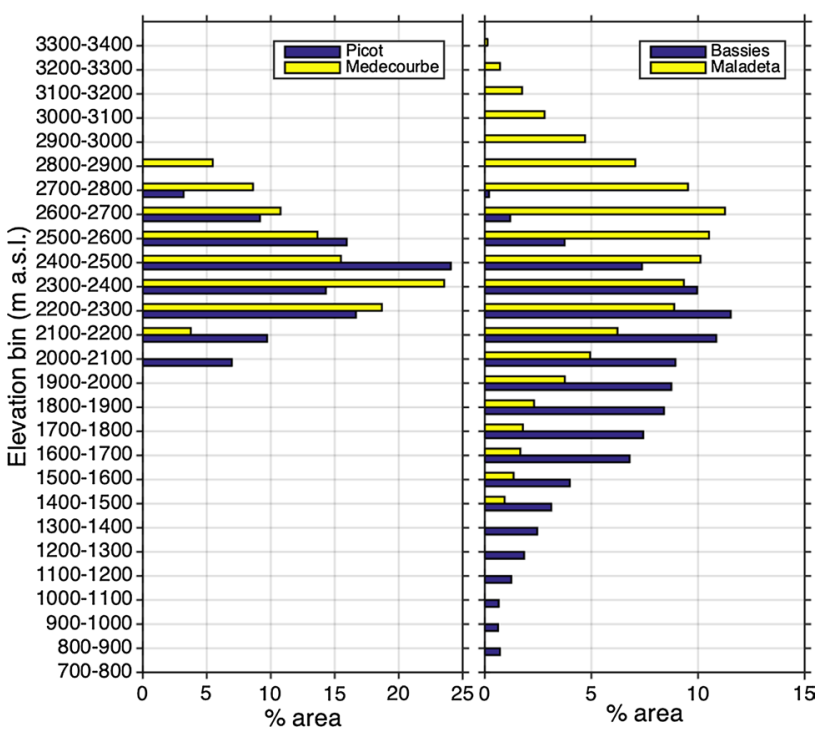

Fig. 8 Hypsometric data for different high- and low-altitude Pyrenean catchments 
Table 2 Mean geomorphic features of some investigated glacial valleys

\begin{tabular}{|c|c|c|c|c|c|c|}
\hline $\begin{array}{l}\text { Geomorphological char- } \\
\text { acteristics }\end{array}$ & Picot & Médécourbe & Bassies & Ossoue & Maladeta & Argentière \\
\hline Altitude summit (m) & 2793 & 2914 & 2976 & 3298 & 3308 & 3530 \\
\hline Current ELA (m) & Above summit & Above summit & Above summit & 3190 & 3205 & 2890 \\
\hline Presence of glacier & No & No (only snow patch) & No & Yes & Yes & Yes \\
\hline $\begin{array}{l}\text { Upper catchment mor- } \\
\text { phology }\end{array}$ & Small steep rockwall & High steep rockwall & Small steep rockwall & Gentle slope & Gentle slope & High steep rockwall \\
\hline LIA moraine & No & $?$ & No & Yes & Yes & Yes \\
\hline Early Holocene moraine & Not identified & Yes & Not identified & $?$ & Yes & Yes \\
\hline YD moraine & Not identified & Yes & Not identified & $?$ & Yes & Yes \\
\hline $\begin{array}{l}\text { Late Glacial/HS1 } \\
\text { moraine }\end{array}$ & Yes & Yes & Yes & Yes & Yes & Yes \\
\hline
\end{tabular}

catchments on the northern and southern slopes of the Pyrenees. The terminal moraines Bompas and Bernière located in Ariège valley were formed between 17.4 and $23.5 \mathrm{kyr}$ (updating of the ${ }^{10} \mathrm{Be}$ CRE ages published by Delmas et al. 2011). Roches moutonnées near Ax-les-Thermes city were ${ }^{10} \mathrm{Be}$ CRE dated at about $16-17.4 \mathrm{kyr}$ (updating of the ${ }^{10} \mathrm{Be}$ CRE ages from Delmas et al. 2011). These data suggest that the large Ariège glacier was already retreating at that time, as confirmed by our Picot record. In the Suc valley, a tributary of Vicdessos river close to our studied sites (Fig. 1), data also suggest that this small glacier was already confined to the upper part of the catchment and probably disappeared definitively from that time, leaving no evidence of moraines formation during the YD and Holocene periods (Jalut et al. 1982; Crest et al. 2017). The Bassies lateral moraine (Crest et al. 2017) at the base of Pic Rouge de Bassies summit (2976 m a.s.l) may also correspond to the Late Glacial-YD transition (based on the ${ }^{10} \mathrm{Be}$ CRE age updating) and may be broadly synchronous with Médécourbe moraines (M1-M3).

On the Spanish slope of the Pyrenees, the same trend is observed in the catchments below the current ELA. Glaciers were retreating during the Late Glacial with an interruption during the HS1 event (Andrieu-Ponel et al. 1988; Calvet et al. 2011; Delmas 2015; Palacios et al. 2015a, b, 2016a, b; Crest et al. 2017). However, the glacier evolution documented on high-altitude accumulation area catchments is different as, for instance, in the Maladeta Valley or in the Marboré Cirque (Garcia Ruiz et al. 2014) located in the southern Central Pyrenees (north face of the Monte Perdido Peak, $42^{\circ}$ $40^{\prime} 0^{\prime \prime} \mathrm{N} ; 0.5^{\circ} 0^{\prime \prime} \mathrm{W} ; 3355 \mathrm{~m}$ cf no. 5 on Fig. 1; Table 2). In these high-altitude accumulation area catchments, a series of glacial stillstands or readvances occurred during the Late Glacial-Holocene transition, between $13.7 \mathrm{kyr}$ and $10.6 \mathrm{kyr}$ according to ${ }^{10} \mathrm{Be}$ CRE ages (Garcia Ruiz et al. 2016a, b; Palacios et al. 2017). During the Holocene, glacial advances occurred during the Neoglacial period and during the Dark Age Cold Period (1.4-1.2 kyr), followed by a melting period during the MCA (Gellatly et al. 1992;
Chueca Cia et al. 2005). Finally, a stage of glacial expansion occurred during the LIA within the Marboré Cirque with at least four advances between the late seventeenth century and the beginning of the nineteenth century, as recorded in other valleys (Pallàs et al. 2006; Gonzales et al. 2008; Ruiz et al. 2014; Oliva et al. 2018). Médécourbe fluctuations during the Late Glacial-early Holocene transition may thus partly match with fluctuations of glaciers composed of high-altitude catchments, because of local effects mentioned above (snow overaccumulation: avalanches, snow drift).

Finally, the Pyrenean moraine records are compared with the French Alps moraine records, highlighting the role of the altitude of the glacier catchments. In the Alps, several studies (Chenet et al. 2010; Hoffman 2018; Protin et al. 2019) showed that glaciers in the Mont Blanc and Ecrins massifs (French Alps) with large accumulation area above the current ELA recorded multiple moraine depositions during the 12-10 kyr period. The Argentière glacier, for instance, was retreating from its Late Glacial extent and oscillated several times during the YD-early Holocene transition before substantially retreating at $10.5 \mathrm{kyr}$. Interestingly, Protin et al. (2019) reconstructed comparable temperature changes during the YD-early Holocene transition with the same PDD approach applied to the Argentière moraine record. Such Late Glacial-early Holocene oscillatory transition was also documented at the base of several glacial valleys in different sectors of the Swiss Alps (Schimmelpfennig et al. 2012, 2014; Moran et al. 2016) and may be comparable with the glacial history in the Central Pyrenees composed of highaltitude accumulation area catchments (Table 2). Dendrochronological studies, moraine records and historical documents (Le Roy et al. 2017; Solomina et al. 2015, 2016) also revealed that several advances occurred during the late Holocene and the LIA, which were until now only observed in the Central Pyrenees at the base of valley glaciers with highaltitude accumulation areas. In the Grande Rousses Massif (Western French Alps), radiocarbon dated high-altitude proglacial Lake Blanc Huez sedimentary record displays 
a maximum glacier extension during the early Holocene, a complete disappearance of glaciers during the Holocene climate optimum and several phases of glacier fluctuations starting from about $5 \mathrm{kyr}$ and reaching a maximum late Holocene advance during the LIA (Simonneau et al. 2013a, b). Such late Holocene glacier fluctuations are also well documented on the northern part of the massif upstream proglacial lake Blanc Bramant (Guyard et al. 2013).

If the altitude of the catchments is an important parameter that drives the accumulation and indirectly the pattern of glacier evolution, new ${ }^{10} \mathrm{Be}$ Holocene chronologies from high-altitude catchments of Pyrenean glaciers are needed. These data would help to confirm this interpretation and underline the specificity of Pyrenean glaciers compared to other glaciers in European and Mediterranean mountain ranges (Solomina et al. 2015).

\section{Conclusion}

New ${ }^{10} \mathrm{Be}$ CRE ages from two glacial valleys in the eastern French Pyrenees allow documenting glacier evolution from the Late Glacial period to the early Holocene. In the Picot valley, two glacier advances were recorded during the Late Glacial about 16 kyr ago during HS1, the glacier disappearing completely thereafter. In the upper Médécourbe valley, several advances were recorded during the Late Glacial-YD transition and early Holocene. Our PDD model suggests that temperature about $5.1{ }^{\circ} \mathrm{C}$ cooler than today, assuming no precipitation changes compared with the current one, would be necessary to form a moraine at the base of the Picot catchment at $2060 \mathrm{~m}$ a.s.l., during HS1. Similarly, our model suggests about a $3.9{ }^{\circ} \mathrm{C}$ cooling to explain a moraine formed during the Late Glacial-YD transition at Médécourbe at $2200 \mathrm{~m}$ a.s.l. We suggest that the size of the accumulation area partly controlled by the altitude of the catchment is an important parameter allowing to explain the glacier dynamics at a regional scale. The dynamics of the glacier in the Picot catchment from the Late Glacial is comparable with other low-altitude catchments in the region. However, this glacier evolution differs from catchments with high-altitude accumulation area located either in the Pyrenees or in the Alps. The fluctuations of the Médécourbe glacier are different from that of the Picot glacier, probably due to local effects.Further studies are required to document the precipitation regime fluctuations related to the westerlies wind belt originating from the Atlantic and impacting the precipitation patterns both in the Pyrenees and in the Alps.

Acknowledgements This work was (co)funded by the Labex DRIIHM, French programme "Investissements d'Avenir" (ANR-11-LABX-0010) which is managed by the ANR (OHM Pyrénées Haut Vicdessos: projects ALTOS 2013 and DGLAP 2016. The production of CRE ages were both funded by the DGLAP 2016 project and the Référentiel
Géologique de la France (RGF program) from the French Geological Survey (BRGM) within the frame of the "RGF Pyrénées" in 2016. The

${ }^{10} \mathrm{Be}$ measurements were performed at the ASTER AMS national facility (CEREGE. Aix-en-Provence) that is supported by the INSU/CNRS, the ANR through the "Projets thématiques d'excellence" program for the "Equipements d'excellence" ASTER-CEREGE action and IRD. We thank M. Biette and A. Destanne de Bernis for their help in the field.

Author contributions VJ, DG and EC conducted the field work; VJ, RB and VR, produced the cosmogenic data. ASTER Team (DB, KK, GA) performed AMS measurements; VF, VJ, produced the PDD results, SG, RM and SB provided the meteorological data; NT, VJ, SG and EC prepared figures and all the authors contributed to writing the paper.

\section{Compliance with ethical standards}

Conflict of interest The authors declare no competing financial interests.

\section{References}

Andrieu-Ponel V, Hubschman J, Jalut G, Hérail G (1988) Chronologie de la déglaciation des Pyrénées françaises. Dynamique de sédimentation et contenu pollinique des paléolacs; application à l'interprétation du retrait glaciaire. Bull Assoc Franç l'étude Quat 25:56-65

Arnold M, Merchel S, Bourlès DL, Braucher R, Benedetti L, Finkel RC, Aumaître G, Gottdang A, Klein M (2010) The French accelerator mass spectrometry facility ASTER: improved performance and developments. Nucl Instrum Methods Phys Res Sect B Beam Interact Mater Atoms 268:1954-1959

Balco G, Briner J, Finkel RC, Rayburn JA, Ridge JC, Schaefer JM (2009) Regional beryllium-10 production rate calibration for lateglacial northeastern North America. Quat Geochronol 4:93-107

Biette M, Jomelli V, Favier V, Chenet M, Agosta C, Fettweiss X, Ho Tong Minh D, Ose K (2018) Estimation des températures au début du dernier millénaire dans l'ouest du Groenland: résultats préliminaires issus de l'application d'un modèle glaciologique de type degré jour sur le glacier Lyngmarksbræen. Géomorphologie 24:31-41

Blard PH, Lavé J, Pik R, Wagnon P, Bourles D (2007) Persistence of full glacial conditions in the central Pacific until 15,000 years ago. Nature 449:591-594

Braithwaite RJ (1985) Calculation of degree-days for glacier-climate research. Zeitung Glelscherkd Glazialgeol 20:1-8

Braithwaite RJ (1995) Positive degree-day factors for ablation on the Greenland ice sheet studied by energy-balance modelling. J Glaciol 41:153-160. https://doi.org/10.3189/S0022143000017846

Braucher R, Guillou V, Bourlès DL, Arnold M, Aumaître G, Keddadouche K, Nottoli E (2015) Preparation of ASTER in-house $10 \mathrm{Be} / 9 \mathrm{Be}$ standard solutions. Nucl Instrum Methods Phys Res Sect B 361:335-340. https://doi.org/10.1016/j.nimb.2015.06.012

Calvet M, Delmas M, Gunnell Y, Braucher R, Bourlès D (2011) Recent advances in research on Quaternary glaciations in the Pyrenees. Dev Quat Sci 15:127-139

Chenet M, Roussel E, Jomelli V, Grancher D (2010) Asynchronous Little Ice Age glacial maximum extent in southeast Iceland. Geomorphology 114:253-260. https://doi.org/10.1016/j.geomo rph.2009.07.012

Chmeleff J, von Blanckenburg F, Kossert K, Jakob D (2010) Determination of the ${ }^{10} \mathrm{Be}$ half-life by multicollector ICP-MS and liquid scintillation counting. Nucl Instrum Methods Phys Res Sect B 268:192-199. https://doi.org/10.1016/j.nimb.2009.09.012 
Chueca J, Julian A, Lopez Moreno JI (2007) Recent evolution (1981-2005) of the Maladeta glaciers Pyrenees Spain: extent and volume losses and their relation with climatic and topographic factors. JOG 53:547-557

Chueca Cia J, Julian A, Saz Sanchez MA, Creus Novau J, López Moreno JI (2005) Responses to climatic changes since the Little Ice Age on Maladeta Glacier (Central Pyrenees). Geomorphology 68:167-182

Claude A, Ivy-Ochs S, Kober F, Antognini M, Salcher B, Kubik PW (2014) The Chirinico landslide (Valle Leventina Southern Swiss Alps): age and evolution. Swiss Geosci 107:273-291

Crest Y, Delmas M, Braucher R, Gunnell Y, Calvet M, Team ASTER (2017) Cirques have growth spurts during deglacial and interglacial periods: evidence from $10 \mathrm{Be}$ and $26 \mathrm{Al}$ nuclide inventories in the central and eastern Pyrenees. Geomorphology 278:60-77

Delmas M (2015) The last maximum ice extent and subsequent deglaciation of the Pyrennes an overview of recent research. Cuad Investig Geogr 41:359-387

Delmas M, Gunnell Y, Braucher B, Calvet M, Bourlès D (2008) Exposure age chronology of the last glaciation in the eastern Pyrenees. Quat Res 69:231-241

Delmas M, Calvet M, Gunnell Y, Braucher B, Bourlès D (2011) Palaeogeography and ${ }^{10} \mathrm{Be}$ exposure-age chronology of Middle and Late Pleistocene glacier systems in the northern Pyrenees: implications for reconstructing regional palaeoclimates. Palaeogeogr Palaeoclimatol Palaeoecol 305:109-122

Delmas M, Calvet M, Gunnell Y, Braucher R, Bourlès D (2012) Les glaciations quaternaires dans les Pyrénées ariègeoises: approche historiographique données paléogéographiques et chronologiques nouvelles. Quaternaire 23:61-85

García-Ruiz JM, Palacios D, de Andrés N, Valero-Garcés BL, LópezMoreno JI, Sanjuán Y (2014) Holocene and Little Ice Age glacial activity in the Marboré Cirque, Monte Perdido Massif, Central Spanish Pyrenees. Holocene 24:1439-1452

García-Ruiz JM, Palacios D, González-Sampériz P, Andrés N, Moreno A, Valero- Garcés B, Gómez-Villar A (2016a) Mountain glacier evolution in the Iberian Peninsula during the Younger Dryas. Quat Sci Rev 138:16-30

García-Ruiz JM, Palacios D, Gonzalez-Samperiz P, de Andres N, Moreno A, Valero-Garces B, Gomez-Villar A (2016b) Evidencias de actividad glaciar durante el Dryas Reciente (12.9-11.7 ka BP) en la Península Iberica. Cuatern Geomorfol 30:9-21

Gascoin S, Hagolle O, Huc M, Jarlan L, Dejoux JF, Szczypta C, Marti R, Sanchez R (2015) A snow cover climatology for the Pyrenees from MODIS snow products. Hydrol Earth Syst Sci 19:2337-2351

Gellatly AF, Grove JM, Switsur VR (1992) Mid-Holocene glacial activity in the Pyrenees. Holocene 2:266-270

González Trueba JJ, Martín Moreno R, Martínez de Pisón E, Serrano E (2008) Little Ice Age glaciation and current glaciers in the Iberian Peninsula. Holocene 18:551-568

Guyard G, Chapron E, St-Onge G, Labrie J (2013) Late-Holocene NAO and oceanic forcing on high-altitude proglacial sedimentation (Lake Bramant, Western French Alps). Holocene 23:1163-1172

Heiri O, Millet L (2005) Reconstruction of Late Glacial summer temperatures from chironomid assemblages in Lac Lautrey (Jura, France). J Quat Sci 20:33-44

Heiri O, Lotter AF, Hausmann S, Kienast F (2003) A chironomid-based Holocene summer air temperature reconstruction from the Swiss Alps. Holocene 13:477-484

Heiri O, Koinig KA, Speotl C, Barrett S, Brauer A, Drescher Schneider R, Gaar D, Ivy-Ochs S, Kerschner H, Luetscher M, Moran A, Nicolussi K, Preusser F, Schmidt R, Schoeneich P, Schweorer C, Sprafke T, Terhorst B, Tinner W (2014) Palaeoclimate records $60-8 \mathrm{ka}$ in the Austrian and Swiss Alps and their forelands. Quat Sci Rev 106:186-205
Hofmann FM (2018) Glacial history of the upper Drac blanc catchment (Ecrins massif French Alps). Quat Sci J 67:37-40

Jalut G, Delibrias G, Dagnac J, Mardones M, Bouhours M (1982) A palaeoecological approach to the last 21,000 years in the Pyrenees: the peat bog of Freychinede (alt $1350 \mathrm{~m}$ Ariège South France). Palaeogeogr Palaeoclimatol Palaeoecol 40:321-359

Jomelli V, Bertran P (2001) Wet snow avalanche deposits in the French Alps: structure and sedimentology. Geogr Ann 83A:15-28

Jomelli V, Khodri M, Favier V, Brunstein D, Ledru MP, Wagnon P, Blard PH, Sicart JE, Braucher R, Grancher D, Bourlès D, Braconnot $P$, Vuille $M$ (2011) Irregular tropical glacial retreat during the Holocene driven by progressive warming. Nature 474:196-199

Jomelli V, Favier V, He F, Liu Z (2016) High altitude temperature changes in the tropical Andes over the last 15000 years estimated from a glaciological model. In: Doy N (Ed) Glaciers: formation climate change and their effects. Nova Science Publishing, New York.

Klein MG, Gottdang A, Mous DJW, Bourlès DL, Arnold M, Hamelin B, Aumaître G, Braucher R, Merche S, Chauvet F (2008) Performance of the HVE 5MV AMS system at CEREGE using an absorber foil for isobar suppression. Nucl Instrum Methods Phys Res Sect B 266:1828-1832. https://doi.org/10.1016/j. nimb.2007.11.077

Korschinek G, Bergmaier A, Faestermann T, Gerstmann UC, Knie K, Rugel G, Wallner A, Dillman I, Dollinger G, von Gosstomski L, Ch KK, Maiti M, Poutivtsev M, Remmert A (2010) A new value for the ${ }^{10} \mathrm{Be}$ half-life by heavyion elastic recoil detection and liquid scintillation counting. Nucl Instrum Methods Phys Res B 268(2):187-191

Lal D (1991) Cosmic ray labeling of erosion surfaces: in situ nuclide production rates and erosion models. Earth Planet Sci Lett 104:424-439

Le Roy M, Deline P, Carcaillet J, Schimmelpfennig I, Ermini M (2017) ${ }^{10} \mathrm{Be}$ exposure dating of the timing of Neoglacial glacier advances in the Ecrins Pelvoux massif Southern French Alps. QSR 178:118-138

Lotter AF, Heiri O, Brooks S, van Leeuwen JFN, Eicher U, Ammann B (2012) Rapid summer temperature changes during Termination 1a: high-resolution multi-proxy climate reconstructions from Gerzensee (Switzerland). Quat Sci Rev 36:103-113

Marti R (2016) Apport des méthodes de télédétection à très hauterésolution spatiale dans l'étude des variations de la cryosphère des Pyrénées. PHD thesis Université Toulouse le Mirail-Toulouse II, p 273

Marti R, Gascoin S, Houet T, Ribière O, Laffly D, Condom T, Monnier P, Schmutz M, Camerlynck C, Tihay JP, Soubeyroux JM, René P (2015) Evolution of Ossoue Glacier (French Pyrenees) since the end of the Little Ice Age. Cryosphere 9:1773-1795

Marti R, Gascoin S, Berthier E, de Pinel M, Houet T, Laffly D (2016) Mapping snow depth in open alpine terrain from stereo satellite imagery. Cryosphere 10:1361-1380

Martin LCP, Blard P-H, Balco G, Lavé J, Delunel R, Lifton N, Laurent V (2017) The CREp program and the ICE-D production rate calibration database: a fully parameterizable and updated online tool to compute cosmic-ray exposure ages. Quat Geochronol 38:25-49. https://doi.org/10.1016/j.quageo.2016.11.006

Millet L, Rius D, Galop D, Heiri O, Brooks SJ (2012) Chironomidbased reconstruction of Late glacial summer temperatures from the Ech palaeolake record (French western Pyrenees). Palaeogeogr Palaeoclimatol Palaeoecol 315-316:86-99

Moran AP, Ivy Ochs S, Schuh M, Christi M, Kerschner H (2016) Evidence of central Alpine glacier advances during the Younger Dryas-early Holocene transition period. Boreas 45:398-410

Morellon M, Perez-Saux A, Corella JP, Buntgen U, Catalan J, Gonzales Samperiz MA, Scussolinni P, Serrano E, Steinhilber R, Stefannova V, Vega-Villarrubia T, Valero-Garces B (2012) A multi 
proxy prespective on millennium long climate variability in the Southern Pyrenees. Clim Past 8:683-700

Navarro- Serrano F, López-Moreno JL, Azorin-Molina C, AlonsoGonzález E, Tomás-Burguera M, Sanmiguel-Vallelado A, Revuelto J, Vicente-Serrano SM (2018) Estimation of near-surface air temperature lapse rates over continental Spain and its mountain areas. Int J Climatol 38(8):3233-3249

Oliva M, Ruiz-Fernández J, Barriendos M, Benito G, Cuadrat JM, Domínguez-Castro F, García-Ruiz JM, Giralt S, Gómez-Ortiz A, Hernández A, López-Costas O, López-Moreno JI, López-Sáez JA, Martínez-Cortizas A, Moreno A, Prohom M, Saze MA, Serranom E, Tejedor E, Trigo RB, Valero-Garcés B, Vicente-Serrano SM (2018) The Little Ice Age in Iberian mountains. Earth Sci Rev 177:175-208

Palacios D, de Andres N, Lopez-Moreno JI, García-Ruiz JM (2015a) Late Pleistocene deglaciation in the upper Gallego valley. Quat Res 83(3):397-414

Palacios D, Gomez-Ortiz A, Andres N, Vazquez-Selem L, SalvadorFranch F, Oliva M (2015b) Maximum extent of late Pleistocene glaciers and last deglaciation of La Cerdanya mountains southeastern Pyrenees. Geomorphology 231:116-129

Palacios D, Andres N, Gomez-Ortiz A, García-Ruiz JM (2016a) Evidence of glacial activity during the Oldest Dryas in the mountains of Spain. In: Hughes PD, Woodward JC (eds) Quaternary glaciation in the mediterranean mountains. Geological Society London, Special Publications, p 433. http://dx doi org/ 10 1144/SP433 10.

Palacios D, Gomez-Ortiz A, Andres N, Salvador F, Oliva M (2016) Timing and new geomorphologic evidence of the Last Deglaciation stages in Sierra Nevada (Southern Spain). Quat Sci Rev 150:110-129

Palacios D, García-Ruiz JM, Andres N, Schimmelpfennig I, Campos N, Leanni L, Team ASTER (2017) Deglaciation in the central Pyrenees during the Pleistocene Holocene transition: timing and geomorphological significance. Quat Sci Rev 162:111-127

Pallàs R, Rodes A, Braucher R, Carcaillet J, Ortuno M, Bordonau J, Bourles D, Vilaplana JM, Masana E, Santanach P (2006) Late Pleistocene and Holocene glaciation in the Pyrenees: a critical review and new evidence from ${ }^{10} \mathrm{Be}$ exposure ages south-central Pyrenees. Quat Sci Rev 25:2937-2963

Pallàs R, Rodes A, Braucher R, Bourles D, Delmas M, Calvet M, Gunnell Y (2010) Small isolated glacial catchments as priority targets for cosmogenic surface exposure dating of Pleistocene climate fluctuations southeastern Pyrenees. Geology 38(10):891-894

Protin M, Schimmelpfennig I, Mugnier JL, Ravanel L, Le Roy M, Deline P, Favier V, Buoncristiani JF, Team A (2019) Climate reconstruction for the Younger Dryas/early Holocene transition and the Little Ice Age based on paleo extents of Argentiere glacier (French Alps). QSR. https://doi.org/10.1016/j.quasc irev.2019.105863

Rasmussen SO, Vinther BM, Clausen HB, Andersen KK (2007) Early Holocene climate oscillations recorded in three Greenland ice cores. Quat Sci Rev 26:1907-1914

René P (2011) Régression des glaciers pyrénéens et transformation du paysage depuis le Petit Âge glaciaire Sud-Ouest Européen. Rev Géogr Pyrénées Sud Ouest 32:5-19
Schimmelpfennig I, Schaefer JM, Akcar N, Ivy-Ochs S, Finkel RC, Schluchter C (2012) Holocene glacier culminations in the Western Alps and their hemispheric relevance. Geology 40:891-894

Schimmelpfennig I, Schaefer JM, Akcar N, Koffman T, Ivy Ochs S, Schwartz R, Finkel RC, Zimmerman S, Schluchter C (2014) A chronology of Holocene and Little Ice Age glacier culminations of the Steingletscher Central Alps Switzerland based on highsensitivity beryllium-10 moraine dating. Earth Planet Sci Lett 393:220-230

Simonneau A, Chapron E, Courp T, Tachikawa K, Le Roux G, Galop D, Garcia M, Desmet M, Bard E (2012) Archives lacustres de l'évolution du climat et des activités humaines récentes dans les Pyrénées ariègeoises au cours de l'Holocène (Etang Majeur, vallée du Haut-Vicdessos, Pyrénées France). Sud Ouest Eur 33:101-116

Simonneau A, Chapron E, Garçon M, Winiarski T, Graz Y, Chauvel C, Debret M, Motellica-Heino M, Desmet M, di Giovanni C (2013a) Tracking Holocene glacial and high-altitude alpine environements fluctuations from minerogenic and organic markers in proglacial lake sediments (Lake Blanc Huez Western French Alps). Quat Sci Rev 89:27-43

Simonneau A, Chapron E, Courp T, Tachikawa K, Le Roux G, Baron S, Galop D, Garcia M, Di Giovanni C, Motellica-Heino M, Mazier F, Foucher A, Houet T, Desmet M, Bard E (2013b) Recent climatic and anthropogenic imprints on lacustrine systems in the Pyrenean Mountains inferred from minerogenic and organic clastic supply (Vicdessos valley Pyrenees France). Holocene 23:1764-1777

Six D, Vincent C (2014) Sensitivity of mass balance and equilibriumline altitude to climate change in the French Alps. J Glaciol 60:874-878

Solomina ON, Bradley RS, Hodgson DA, Ivy-Ochs S, Jomelli V, Mackintosh AN, Nesje A, Owen LA, Wanner H, Wiles GC, Young NE (2015) Holocene glacier fluctuations. Quat Sci Rev 111:9-34

Solomina O, Bradley RS, Jomelli V, Geirsdottir A, Kaufman D, Koch J, Masiokas M, Miller G, Nesje A, Nicolussi K, Owen L, Wanner H, Wiles G, Yang B (2016) Glacier fluctuations in the last 2000 years. QSR 149:61-90

Stone JO (2000) Air pressure and cosmogenic isotope production. J Geophys Res 105:23753-23759

Szczypta C, Gascoin S, Houet T, Hagolle O, Dejoux J-F, Vigneau C, Fanise $\mathrm{P}$ (2015) Impact of climate and land cover changes on snow cover in a small Pyrenean catchment. J Hydrol 521:84-99. https ://doi.org/10.1016/j.jhydrol.2014.11.060

Ward GK, Wilson SR (1978) Procedures for comparing and combining radiocarbon age determinations: a critique. Archaeometry 20:19-31. https://doi.org/10.1111/j.1475-4754.1978.tb00208.x

Young NE, Schaefer JM, Briner JP, Goehring BM (2013) A ${ }^{10} \mathrm{Be}$ production-rate calibration for the Arctic: $\mathrm{a}^{10} \mathrm{Be}$ production-rate calibration for the Arctic. J Quat Sci 28:515-526. https://doi. org/10.1002/jqs.2642

Publisher's Note Springer Nature remains neutral with regard to jurisdictional claims in published maps and institutional affiliations. 